\title{
Cluster of differentiation 96 as a leukemia stem cell-specific marker and a factor for prognosis evaluation in leukemia
}

\author{
WEN DU ${ }^{1 *}$, YANJIE HU ${ }^{1 *}$, CONG LU $^{1}$, JUAN LI ${ }^{1}$, WEI LIU ${ }^{1}$, YANLI HE ${ }^{1}$, PING WANG ${ }^{1}$, \\ CHEN CHENG $^{2}$, YU HU ${ }^{3}$, SHIANG HUANG ${ }^{1}$ JUNXIA YAO $^{1}$ and JIN'E ZHENG ${ }^{1}$ \\ ${ }^{1}$ Center for Stem Cell Research and Application, ${ }^{2}$ Tumor Center, ${ }^{3}$ Institute of Hematology, Union Hospital, \\ Tongji Medical College, Huazhong University of Science and Technology, Wuhan, Hubei 430022, P.R. China
}

Received December 15, 2014; Accepted February 25, 2015

DOI: $10.3892 / \mathrm{mco} .2015 .552$

\begin{abstract}
Resistance to chemotherapy is a major challenge for leukemia treatment. It has been suggested that leukemia stem cells (LSCs), a small pool of self-renewing leukemic cells, play important roles in development of chemotherapy resistance. The expression of cluster of differentiation 96 (CD96), a potential marker for LSCs, was investigated in CD $34^{+} \mathrm{CD} 38^{-}$cells of 105 acute leukemia (AL) patients by flow cytometry. The data showed that all the $\mathrm{CD} 34^{+}$, CD $34^{+} \mathrm{CD} 38^{-}$and $\mathrm{CD} 34^{+} \mathrm{CD} 38^{-} \mathrm{CD}^{-} 6^{+}$proportions were much higher in $\mathrm{AL}$ compared to the normal control $(\mathrm{P}<0.01)$, while a clear difference was identified in the $\mathrm{CD} 34^{+} \mathrm{CD} 38^{-}$and CD $34^{+} \mathrm{CD} 38^{-} \mathrm{CD}^{-} 6^{+}$proportions between acute lymphoid leukemia and acute myeloid leukemia (AML). However, all the AML patients with $>15 \%$ CD $34^{+} \mathrm{CD} 38^{-}$cells achieved complete remission (CR), suggesting that as an LSC-rich population, the amount of $\mathrm{CD} 34^{+} \mathrm{CD} 38^{-}$cells may not be positively associated with the proportion of refractory LSCs. The mean percentage of the co-presence of CD96 expression itself was similar in AML patients with $\mathrm{CR}$ and non-CR $(\mathrm{P}>0.05)$. However, the CR rate was significantly higher in the AML population with $<10 \%$ CD96 expressed, which indicated that a distinct sub-group of $\mathrm{CD} 34^{+} \mathrm{CD} 38^{-} \mathrm{CD} 96^{+}$cells may still contribute to the drug resistance or poor prognosis.
\end{abstract}

\section{Introduction}

According to the cancer stem cell model, the small pool of self-renewing cancer stem cells must be eliminated in order

Correspondence to: Ms. Junxia Yao or Ms. Jin'e Zheng, Center for Stem Cell Research and Application, Union Hospital, Tongji Medical College, Huazhong University of Science and Technology, 1277 Jiefang Road, Wuhan, Hubei 430022, P.R. China

E-mail: yaojunxia@yahoo.com

E-mail: zhengjine2013@163.com

*Contributed equally

Key words: leukemia stem cells, minimal residual disease, acute leukemia, prognosis, cluster of differentiation 96 to eradicate the tumor (1-4). Acute myeloid leukemia (AML) is a developmental disease characterized by clonal growth and subsequent accumulation of myeloid blasts in the bone marrow (BM), which is initiated and maintained by a subset of self-renewing leukemia stem cells (LSCs). Thus far, human AML stem cells are the most extensively characterized cancer stem cell population. LSCs share numerous properties with hematopoietic stem cells (HSC) with the ability of self-renewal. Thus, it has been suggested that the clonal progression of preleukemia may occur in a succession of HSC subclones until augmented or poorly regulated self-renewal pathways are activated, leading to the emergence of final stage LSCs usually at the level of a downstream progenitor (5).

A number of studies have shown that LSC-enriched populations are resistant to various chemotherapy agents and are therefore possibly responsible for the outgrowth of minimal residual disease, which in turn is believed to cause relapse $(6,7)$. Thus, the expression profile of LSCs specific cell surface markers may be used as a prognosis factor to predict the drug response in AML patients. Similar to the normal HSCs, AML-LSC are enriched in the CD34 ${ }^{+} \mathrm{CD} 38^{-}$population (8). However, AML-LSCs also express certain unique cell surface marker combinations, such as $\mathrm{CD} 123^{\text {high }} \mathrm{CD} 117^{+}$, $\mathrm{CD} 90^{+}, \mathrm{CD} 47^{+}$and intermediate aldehyde dehydrogenase activity (9-13). CD96 (T cell-activated increased late expression) is a transmembrane glycoprotein possessing three extracellular immunoglobulin-like domains (14), which is expressed by T and NK cells but not the majority of B cells, monocytes and granulocytes in human peripheral blood cells (15). Notably however, CD96 has been identified as an LSC-specific marker in human AML $(16,17)$. Although, the functions and prognosis value of CD96 expression in human AML remains unclear.

The present study investigated the potential co-association between CD96 expression and chemotherapy response in AML, acute lymphoid leukemia (ALL) and mixed lineage acute leukemia (MAL) patients, to increase the understanding of the role of CD96 in leukemia diagnosis and prognosis.

\section{Materials and methods}

Patient samples. BM samples of 105 acute leukemia (AL) patients presenting with AML, ALL and MAL at the Union 
Hospital Center for Stem Cell Research and Application (Wuhan, China) were obtained following informed consent at diagnosis and following chemotherapeutic treatment. A total of 15 normal BM samples were collected as control. The mean age was 48 years and ranged from 2 month to 82 years. The study was approved by the Research Ethics Committee at the Union Hospital. Patient distributions are shown in Table I. Diagnosis and identification of subtypes for the patients was based on morphology using the French-American-British classification, immune-phenotyping, molecular genetics and cytogenetics, and fluorescence in situ hybridization (18). All the AML patients were induced by a dose-adjusted regimen, except AML-M3. The complete remission (CR) group was defined as first CR. When the patient could not achieve the first CR within two induction treatments, or relapsed in 6 months after the first $C R$, they were classified into the non-CR (NCR) group.

Flow cytometry. The majority of the samples were analyzed freshly. Red blood cells (RBCs) were lysed using a 10 min lysing procedure on ice with $10 \mathrm{ml}$ lysis buffer $\left[155 \mathrm{mmol} / \mathrm{N} \mathrm{NH}_{4} \mathrm{Cl}\right.$, $10 \mathrm{mmol} / 1 \mathrm{KHCO}_{3}, 0.1 \mathrm{mmol} / 1 \mathrm{Na}_{2}$ and ethylenediaminetetraacetic acid ( $\mathrm{pH}$ 7.4)] and washed with phosphate-buffered agar (PBA) [phosphate-buffered saline (PBS) containing $0.1 \%$ bovine serum albumin]. The monoclonal antibodies (10 $\mu \mathrm{l}$; BD Biosciences, Franklin Lakes, NJ, USA) CD38 fluorescein isothiocyanate, CD34 cy-chrome and CD96 phycoerythrin were added respectively to a certain volume of whole BM according to the cell counts $\left(\sim 5 \times 10^{6}\right.$ cells/tube). Subsequently the samples were maintained in the dark at $4^{\circ} \mathrm{C}$ for $30 \mathrm{~min}$. The samples were lysed with fluorescence-activated cell sorting (FACS) lysing solution (BD Biosciences) for $10 \mathrm{~min}$, followed by washing with PBA once at $\sim 1,000 \mathrm{x} \mathrm{g}$ at $4^{\circ} \mathrm{C}$ for $5 \mathrm{~min}$. Finally, the cell pellets were resuspended in $300 \mu \mathrm{l}$ PBS and the data was collected by FACS Calibur ${ }^{\mathrm{TM}}$ (BD Biosciences).

Statistical analysis. The data were analyzed using the SPSS software package (version 16.0 for Windows; SPSS, Inc., Chicago, IL, USA) in the study. All the variables were presented as mean values and standard error (SE) or median and interquartile range with the independent samples group t-test or $\chi^{2}$ test. Analysis of the prognosis was performed using the Wilcoxon signed ranks. All the statistical tests were two-sided and $\mathrm{P}<0.05$ was considered to indicate a statistically significant difference.

\section{Results}

CD34/CD38/CD96 expression in AL patients. The frequencies of $\mathrm{CD} 34^{+}, \mathrm{CD} 34^{+} \mathrm{CD} 38^{-}$and $\mathrm{CD} 34^{+} \mathrm{CD} 38^{-} \mathrm{CD}^{-} 6^{+}$populations were analyzed in $\mathrm{BM}$ nucleated cells from a cohort of $105 \mathrm{AL}$ and 15 healthy volunteers. The information of the patients and healthy volunteers as normal controls is summarized in the Table I. A total of 20,000 nucleated cells were analyzed for each specimen to evaluate the expression of CD34 and 2,000 gated-CD34 ${ }^{+}$cells were collected when analyzing with CD38 and CD96.

As expected, the frequency of the $\mathrm{CD} 34^{+}$population in nucleated cells was low $(<4.6 \%)$ in all the healthy volunteers
Table I. Distribution of the patients in the study.

\begin{tabular}{lrc}
\hline Classification & No. & Gender, M/F \\
\hline Normal & 15 & $6 / 9$ \\
AL & 105 & $59 / 46$ \\
AML & 87 & $49 / 38$ \\
M0 & 7 & $5 / 2$ \\
M1 & 10 & $6 / 4$ \\
M2 & 47 & $25 / 22$ \\
M3 & 4 & $1 / 3$ \\
M4 & 10 & $6 / 4$ \\
M5 & 5 & $3 / 2$ \\
M6 & 3 & $2 / 1$ \\
M7 & 1 & $1 / 0$ \\
ALL & 15 & $8 / 7$ \\
MAL & 3 & $2 / 1$
\end{tabular}

M, male; F, female; AL, acute leukemia; AML, acute myeloid leukemia; ALL, acute lymphoid leukemia; MAL, mixed lineage acute leukemia.

with the mean of $2.07 \%$. However, its expression varied significantly in AL patients, with the mean value of $35.20 \%$ (median 30.26\%, SE 0.27\%), which was much higher in comparison to the normal controls $(\mathrm{P}<0.01)$. Similarly, as shown in Figs. 1 and 2, the proportion of the $\mathrm{CD} 34^{+} \mathrm{CD} 38^{-}$population in nucleated cells was $<0.6 \%$ (mean $0.10 \%$, median $0.03 \%$, SE $0.01 \%$ ) in all the healthy volunteers, which was $9.22 \%$ (median $2.36 \%$, SE $0.14 \%$ ) in AL patients, indicating the significant difference between them $(\mathrm{P}<0.01)$. Subsequently, the CD96 expression in $\mathrm{CD} 4^{+} \mathrm{CD} 38^{-}$cells was examined. As shown in Figs. 1 and 3, the $\mathrm{CD} 34^{+} \mathrm{CD} 38^{-}$cells from healthy volunteers had less expression of CD96, with the mean of $7.78 \%$ (median $4.00 \%$, SE $0.99 \%$ ), while the proportion was as high as $29.36 \%$ (median $7.32 \%$, SE $0.40 \%$ ) in the $105 \mathrm{AL}$ patients. The difference had clear significance $(\mathrm{P}<0.01)$.

The CD34 expression also varied significantly in AML patients, with the mean value of $35.12 \%$ (median $27.80 \%$, SE $0.32 \%$ ), which was significantly higher compared to the healthy controls $(\mathrm{P}<0.01)$, but was close to the total $\mathrm{AL}$ samples. Similarly, the proportion of the CD $34^{+} \mathrm{CD} 38^{-}$population in nucleated cells in healthy volunteers was much lower compared to the AML patients $(\mathrm{P}<0.01)$, which was at the mean of $6.91 \%$ (median $1.25 \%$, SE $0.15 \%$ ). In addition, CD96 expression on $\mathrm{CD} 34^{+} \mathrm{CD} 38-$ cells in $\mathrm{AML}$ patients (mean $26.71 \%$, median $5.57 \%$, SE $0.33 \%$ ) was also significantly higher compared to the normal control $(\mathrm{P}<0.01)$.

The CD34 expression in ALL patients was at the mean value of $39.15 \%$ (median $35.03 \%$, SE $2.33 \%$ ), which was significantly higher compared to the healthy controls $(\mathrm{P}<0.01)$, but there was no difference when comparing with the AML patients $(\mathrm{P}>0.05)$. The $\mathrm{CD} 34^{+} \mathrm{CD} 38^{-}$cells in the ALL patients was at the mean value of $24.48 \%$ (median $23.22 \%$, SE $1.44 \%$ ), which was significantly higher compared to the healthy controls $(\mathrm{P}<0.01)$, but still much lower than the AML patients $(\mathrm{P}<0.01)$. The CD96 expression in the $\mathrm{CD} 34^{+} \mathrm{CD} 38^{-}$cells in the ALL patients (mean $11.34 \%$, median $0.74 \%$, SE $1.86 \%$ ) 


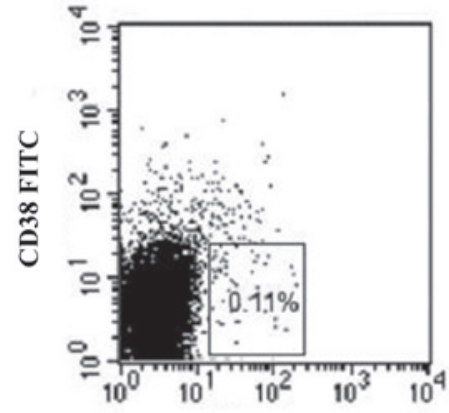

CD34 cychrome

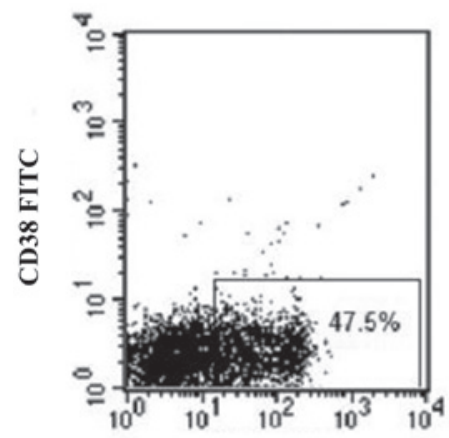

CD34 cychrome
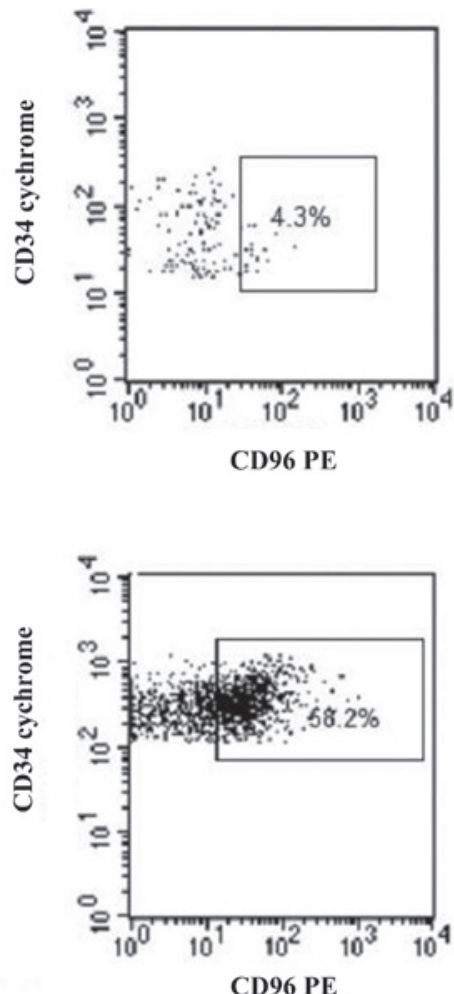

Figure 1. Dot plot of cluster of differentiation 34 (CD34)/CD38/CD96 expression in normal controls and AL patients by flow cytometry. The proportion of the $\mathrm{CD} 34^{+} \mathrm{CD} 38^{-}$population in nucleated cells from normal controls was $<0.6 \%$. The CD34 ${ }^{+} \mathrm{CD} 38^{-}$cells in normal controls expressed CD96 less, while CD96 was significantly higher in AL patients. AL, acute leukemia.

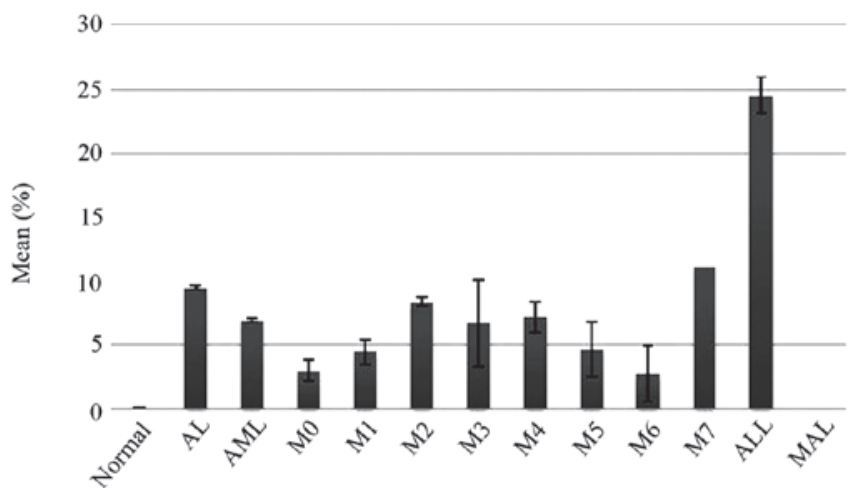

Figure 2. Mean of $\mathrm{CD}^{3} 4^{+} \mathrm{CD} 38^{-}$proportions in nucleated cells in normal controls and AL patients. The proportion of the $\mathrm{CD} 34^{+} \mathrm{CD} 38^{-}$population in nucleated cells was $<0.6 \%$ (mean $0.10 \%$, median $0.03 \%$, SE $0.01 \%$ ) in all healthy volunteers, which was $9.22 \%$ (median $2.36 \%$, SE $0.14 \%$ ) in AL patients, indicating a significant difference between them $(\mathrm{P}<0.01) . \mathrm{CD}$, cluster of differentiation; SE, standard error; AL, acute leukemia; AML, acute myeloid leukemia; ALL, acute lymphoid leukemia; MAL, mixed lineage acute leukemia.

was similar to the normal controls $(\mathrm{P}>0.05)$ and lower than the AML patients $(\mathrm{P}<0.05)$. With regards to MAL, further analysis or comparisons were not performed due to the limited cases.

CD34/CD38/CD96 expression in the AML subtypes. The differences between 3 subtypes of AML (M1, M2, and M4) were considered, which had $\geq 10$ samples in each group. Only the CD34 expression in M2 and M4 patients had a statistical

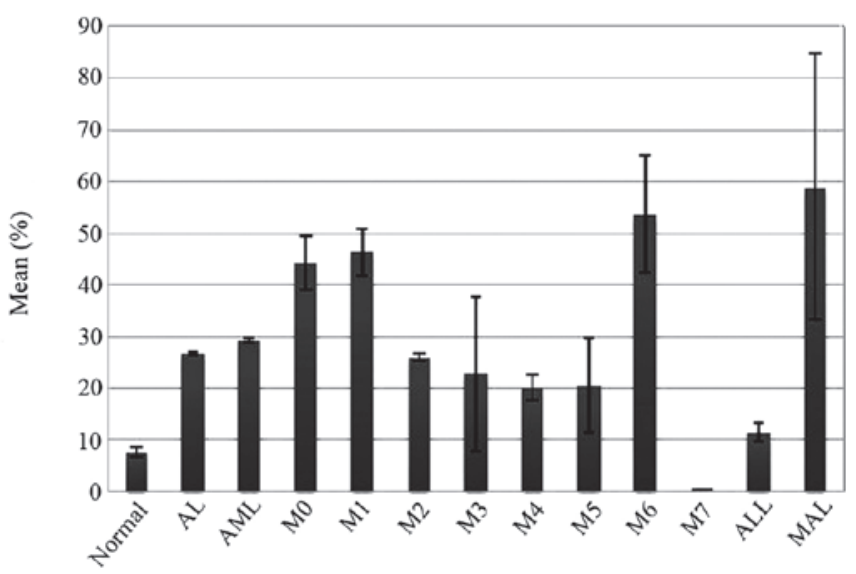

Figure 3. Mean of $\mathrm{CD} 96$ expression on $\mathrm{CD} 34^{+} \mathrm{CD} 38^{-}$cells in normal controls and AL patients. The $\mathrm{CD} 34^{+} \mathrm{CD} 38^{-}$cells from healthy volunteers expressed CD96 less, with the mean of $7.78 \%$ (median $4.00 \%$, SE $0.99 \%$ ), while the proportion was as high as $29.36 \%$ (median $7.32 \%$, SE $0.40 \%$ ) in 105 AL patients. The difference was statistically significant $(\mathrm{P}<0.01)$. CD, cluster of differentiation; SE, standard error; AL, acute leukemia; AML, acute myeloid leukemia; ALL, acute lymphoid leukemia; MAL, mixed lineage acute leukemia.

difference $(\mathrm{P}<0.05)$. None of the other indices, including $\mathrm{CD}_{3}{ }^{+}$cell percentages in the M1 and M2 or M1 and M4 groups, $\mathrm{CD} 34^{+} \mathrm{CD} 38^{-}$proportions and $\mathrm{CD} 96$ expression in the 3 subtypes, were identified as significantly difference $(\mathrm{P}>0.05)$.

Association of $\mathrm{CD} 4^{+} \mathrm{CD} 38^{-}$and $\mathrm{CD} 96^{+}$expression with the chemotherapy response in AML patients. The presence of LSCs has been proposed to be an important reason for drug 
Table II. CD $34^{+} \mathrm{CD} 38^{-}$proportions and the chemotherapy response of AML patients.

\begin{tabular}{lccc}
\hline $\begin{array}{l}\text { CD34 }{ }^{+} \text {CD38 cells in } \\
\text { CD34 cells }\end{array}$ & $\begin{array}{c}\text { NCR } \\
\text { cases }\end{array}$ & $\begin{array}{c}\text { CR } \\
\text { cases }\end{array}$ & Subtotal \\
\hline$\geq 15 \%$ & 0 & 10 & 10 \\
$<15 \%$ & 17 & 28 & 45 \\
Subtotal & 17 & 38 & 55 \\
\hline
\end{tabular}

$\mathrm{CD}$, cluster of differentiation; AML, acute myeloid leukemia; CR, complete remission; NCR, non CR.

Table III. CD96 expression in $\mathrm{CD} 34^{+} \mathrm{CD} 38^{-}$cells and the response for chemotherapy of AML patients.

\begin{tabular}{lccc}
\hline CD34 ${ }^{+} \mathrm{CD} 38^{-C D} 96^{+}$cells in & NCR & CR & \\
CD34 ${ }^{+} \mathrm{CD} 38^{-}$cells & 11 & 12 & 23 \\
$\geq 10 \%$ & 6 & 26 & 32 \\
$<10 \%$ & 17 & 38 & 55 \\
Subtotal & & cases & Subtotal \\
\hline
\end{tabular}

$\mathrm{CD}$, cluster of differentiation; AML, acute myeloid leukemia; CR, complete remission; NCR, non CR.

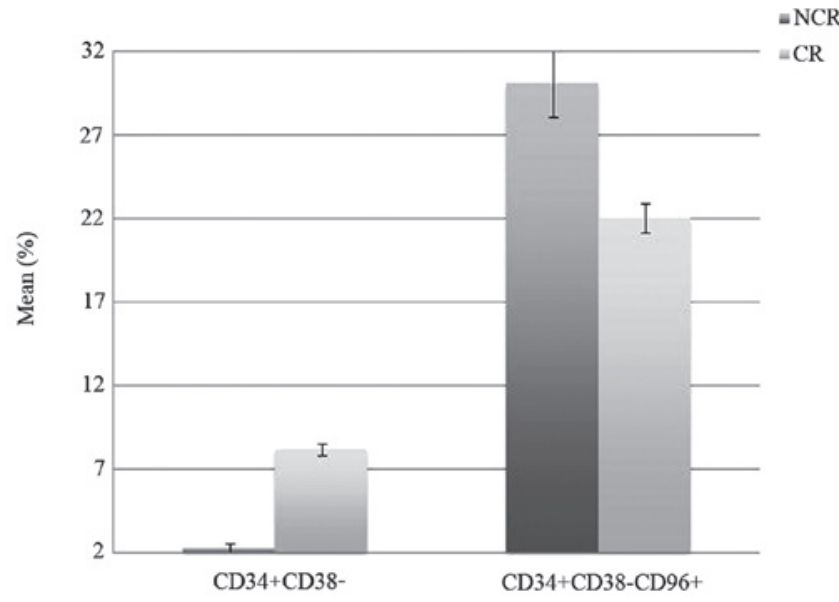

Figure 4. Mean of $\mathrm{CD} 34^{+} \mathrm{CD} 38^{-}$and $\mathrm{CD}^{-} 6^{+}$proportions in newly diagnosed AML patients who achieved CR or NCR. The results showed that in $17 \mathrm{NCR}$ AML patients, the average $\mathrm{CD} 34^{+} \mathrm{CD} 38^{-}$proportion was at the mean of $2.31 \%$ (median $0.23 \%$, SE $0.28 \%$ ), which was different from that in $38 \mathrm{CR}$ patients with the mean of $8.19 \%$ (median $1.97 \%$, SE $0.34 \%)(\mathrm{P}<0.05)$. However, there was no difference in the mean of $\mathrm{CD} 96$ expression on the $\mathrm{CD} 34^{+} \mathrm{CD} 38$ fractions between the two groups of AML patients $(\mathrm{P}>0.05)$. $\mathrm{CD}$, cluster of differentiation; SE, standard error; AML, acute myeloid leukemia; CR, complete remission; NCR, non CR.

resistance in AML patients. Thus, the potential co-association between the $\mathrm{CR}$ rates and frequencies of LSC-enriched populations were examined in the AML patients. A total of 55 AML patients with necessary clinical information to evaluate chemotherapy response were included in the analysis. The overall CR rate in this cohort of patients was $69.1 \%$ (38/55).
These patients were divided into two groups according to the frequencies of the $\mathrm{CD} 34^{+} \mathrm{CD} 38^{-}$population in nucleated cells. The results showed that in 17 NCR patients, the $\mathrm{CD} 34^{+} \mathrm{CD} 38^{-}$proportion was at the mean of $2.31 \%$ (median $0.23 \%$, SE $0.28 \%$ ), which was different from that in $38 \mathrm{CR}$ patients with the mean of $8.19 \%$ (median $1.97 \%$, SE $0.34 \%)(\mathrm{P}<0.05)$. However, further data suggested that all 10 cases of AML patients with $>15 \% \mathrm{CD} 34^{+} \mathrm{CD} 38^{-}$cells achieved CR, while 17 out of 45 patients (38\%) who had $<15 \%$ $\mathrm{CD} 34^{+} \mathrm{CD} 38^{-}$cells remained NCR $(\mathrm{P}<0.01)$, as shown in Fig. 4 and Table II. Therefore, all the 17 NCR patients had $<15 \%$ $\mathrm{CD} 34^{+} \mathrm{CD} 38^{-}$cells in nucleated cells.

Subsequently, whether CD96 expression in the $\mathrm{CD} 34^{+} \mathrm{CD} 38^{-}$cells was correlated with drug resistance in AML patients was examined. The results showed there was no difference in the $\mathrm{CD} 96^{+}$proportion between the $17 \mathrm{NCR}$ patients at the mean of $30.09 \%$ and $38 \mathrm{CR}$ patients at the mean of $22.09 \%$ ( $\mathrm{P}>0.05)$. Of note, $65 \%$ NCR patients had $>10 \%$ $\mathrm{CD} 34^{+} \mathrm{CD} 38^{-} \mathrm{CD}^{-} 6^{+}$population in the $\mathrm{CD} 34^{+} \mathrm{CD} 38^{-}$cells, while only $32 \% \mathrm{CR}$ patients had the same level of $\mathrm{CD} 34^{+} \mathrm{CD} 38{ }^{-\mathrm{CD}} 96^{+}$population $(\mathrm{P}<0.01)$. Therefore, 11 out of 23 patients $(48 \%)$ with $>10 \%$ CD96 expression remained NCR, while the rate in patients with $<10 \%$ CD96 cells was only $19 \%$ $(\mathrm{P}<0.01)$. The results are shown in Fig. 4 and Table III.

\section{Discussion}

CD96 had previously been reported to express on T and NK cells, but not on B cells, granulocytes, monocytes or RBCs $(17,19)$. However, recent studies suggested that CD96 was a putative maker expressed by LSCs in AML patients. Although the physiological functions of CD96 on AML-LSCs are unknown, it may contribute to their adhesion to the BM compartment. To increase the understanding of the association of $\mathrm{CD} 96$ expression and $\mathrm{CD} 34^{+} \mathrm{CD} 38^{-}$stem cell markers and subsequently to reveal the role of CD96 in leukemia, the CD34/CD38/CD96 expression and the clinical characteristics in $105 \mathrm{AL}$ patients, including $87 \mathrm{AML}, 15 \mathrm{ALL}$ and $3 \mathrm{MAL}$, and 15 healthy volunteers as normal controls were examined.

As expected, the frequency of the $\mathrm{CD} 34^{+}$population in nucleated cells was much lower than that in the AL patients $(\mathrm{P}<0.01)$, which was in the same situation as $\mathrm{CD} 34^{+} \mathrm{CD} 38^{-}$

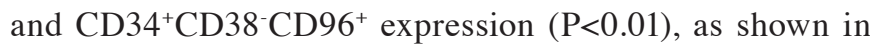
Figs. 1-3. Advanced analysis also showed that AML and ALL had higher $\mathrm{CD} 34^{+}$and $\mathrm{CD} 34^{+} \mathrm{CD} 38^{-}$cells compared to the normal controls $(\mathrm{P}<0.01)$. These results were consistent with previous studies $(13,20,21)$. However, the present data also showed that although there were high frequencies and no difference in $\mathrm{CD} 34^{+}$expression between AML and ALL $(\mathrm{P}>0.05)$, the $\mathrm{CD} 34^{+} \mathrm{CD} 38^{-}$cells in ALL patients was significantly lower than that in the AML patients $(\mathrm{P}<0.01)$. In addition, there were still evident differences of CD96 expression on $\mathrm{CD} 34^{+} \mathrm{CD} 38$ cells in ALL patients with that in AML; the former was similar to the normal controls $(P>0.05)$ and lower than the AML patients $(\mathrm{P}<0.05)$. The results suggested that, regardless of the several studies indicating a population of LSC exhibiting a CD34+CD38- phenotype in ALL and AML $(22,23)$, the proportions were different. CD96 may not appear to be a potential distinguished LSCs marker in ALL. However, except for the statistical difference of CD34 
expression in the M2 and M4 patients $(\mathrm{P}<0.05)$, none of the other indices, including the $\mathrm{CD} 34^{+}$cell percentages in the M1 and $\mathrm{M} 2$ or M1 and M4 groups, $\mathrm{CD} 34^{+} \mathrm{CD} 38^{-}$proportions and CD96 expression in the 3 subtypes of AML (M1, M2 and M4), were identified as different $(\mathrm{P}>0.05)$. Sufficient cases may be studied to evaluate the diversity.

Numerous studies were performed to reveal the characteristics and function of leukemia stem cells. One of the most prevalent aims focused on the $\mathrm{CD} 34^{+} \mathrm{CD} 38^{-} \mathrm{LSC}$-enriched cells, which had been proposed as an important factor in drug resistance. Certain studies described that the fraction of $\mathrm{CD} 4^{+} \mathrm{CD} 38^{-}$cells at the time of diagnosis exhibited a significant correlation with poor prognosis in childhood ALL of B-cell lineage and AML $(20,21)$. Of note, the present results showed that in $17 \mathrm{NCR}$ patients out of 55 AML cases, the mean of $\mathrm{CD} 34^{+} \mathrm{CD} 38^{-}$proportion in $\mathrm{CD} 34^{+}$cells at the new diagnosis time was lower compared to the $38 \mathrm{CR}$ AML patients $(\mathrm{P}<0.05)$. Furthermore, all 10 cases of AML patients with $>15 \% \mathrm{CD}^{2} 4^{+} \mathrm{CD} 38^{-}$cells achieved $\mathrm{CR}$, while 17 out of 45 patients $(38 \%)$ who had $<15 \% \mathrm{CD} 34^{+} \mathrm{CD} 38^{-}$cells remained NCR $(\mathrm{P}<0.01)$, as shown in Fig. 4 and Table II. In summary, all $17 \mathrm{NCR}$ patients had $<15 \% \mathrm{CD} 34^{+} \mathrm{CD} 38^{-}$cells in nucleated cells. However, conflicting results were not identified between our and the previous study. The previous studies analyzed the fraction of $\mathrm{CD} 34^{+} \mathrm{CD} 38^{-}$cells based on total abnormal cells, which may or may not include a significant number of $\mathrm{CD} 34^{+}$cells. The $\mathrm{CD} 34^{+} \mathrm{CD} 38^{-}$cells were counted based on pure $\mathrm{CD} 34^{+}$cells, which varied significantly in all the AL patients even in a similar proportion of abnormal cells, but may be more comparable. This type of percentage was selected as it may avoid the inaccuracy of too few CD $34^{+} \mathrm{CD} 38^{-}$cells for the rare $\mathrm{CD} 34^{+}$cells, and waive the difference resulting from the unbalance of various amounts of $\mathrm{CD}_{3} 4^{+}$cells in the abnormal cells. The frequencies should not simply be compared. The $\mathrm{CD} 34^{+} \mathrm{CD} 38^{-}$proportion in the $\mathrm{CD} 4^{+}$cells could also provide a significant explanation for the prognosis of AL. In addition, the results verified that only the $\mathrm{CD}_{34}{ }^{+} \mathrm{CD} 38^{-}$cells were an enriched marker of LSCs. The amount of LSCs may not be positively correlated with the $\mathrm{CD} 34^{+} \mathrm{CD} 38^{-}$proportion in $\mathrm{CD} 34^{+}$cells, or conversely, lower $\mathrm{CD} 34^{+} \mathrm{CD} 38^{-}$frequencies $(<15 \%)$ in $\mathrm{CD}^{-} 4^{+}$cells may suggest more non-developed LSCs. These results indicated that AML-LSC could be distinguished from normal HSC by the presence of CD96 expression. This finding suggested that CD96 may be an excellent candidate target for antibody therapy against LSC. The therapy may be developed by the CD96 antibodies that induce cytotoxicity, such as antibody-dependent cell-mediated cytotoxicity, augmented macrophage phagocytosis or complement dependent cytotoxicity (24). Further research should focus on identifying the real LSCs.

Subsequently, the mean $\mathrm{CD} 6^{+}$proportion between 17 NCR patients and $38 \mathrm{CR}$ patients was compared and there was no difference $(\mathrm{P}>0.05)$. Notably, as shown in Fig. 4 and Table III, the data showed that $65 \%$ of NCR patients had $>10 \% \mathrm{CD} 34^{+} \mathrm{CD} 38^{-} \mathrm{CD}^{-} 6^{+}$population in $\mathrm{CD} 34^{+} \mathrm{CD} 38^{-}$cells, while only $32 \% \mathrm{CR}$ patients had the same level of $\mathrm{CD} 34^{+} \mathrm{CD} 38^{-} \mathrm{CD}^{-} 6^{+}$population $(\mathrm{P}<0.01)$. In summary, 11 out of 23 patients $(48 \%)$ with $>10 \%$ CD96 expression remained NCR, while the rate in patients with $<10 \%$ CD96 cells was only $19 \%(\mathrm{P}<0.01)$. The results strongly indicated that a higher expression of CD96 (>10\%) may promote a poor response for chemotherapy, which may be closely associated with primary resistant. Of note, CD96 was proved to be an efficient identical marker of LSCs in CD $34{ }^{+} \mathrm{CD} 38^{-}$groups, which was consistent with previous studies $(16,17)$. For the limit of adherence and follow-up of the patients, only the outcomes in 55 AML patients with completed clinical data were analyzed, however, it may have a certain association with other types or subtypes of leukemia that require further research.

CD96 expression was also evaluated in CD34 ${ }^{+} \mathrm{CD} 38^{-}$cells in 14 high-risk MDS BM samples. Although CD96 expression was much higher compared to the normal control, no evidence showed that the $\mathrm{CD} 34^{+} \mathrm{CD} 38^{-}$or $\mathrm{CD} 34^{+} \mathrm{CD} 38^{-} \mathrm{CD} 96^{+}$proportion was associated with MDS chemotherapy efficacy or the prognosis. However, MDS stem cells exhibit a deranged phenotype that is different from normal and AML stem cells, and this may cause them to be particularly difficult to eradicate by therapies targeted against surface antigens.

In conclusion, CD96 was frequently expressed in the CD $34^{+} \mathrm{CD} 38^{-}$LSC population in AL patients. CD96 is significantly associated with the response for chemotherapy in AML patients, which strongly suggested that CD96 may be a marker of LSCs, candidate therapeutic target and prediction factor in AL patients.

\section{Acknowledgements}

The authors acknowledge the Union Hospital and Center for Stem Cell Research and Application for supporting the research. The present study was supported by the Morning Program, Wuhan Science and Technology Bureau (grant no. 201150431122) and the National Young Scientist's Program of China (grant no. 81100356).

\section{References}

1. Reya T, Morrison SJ, Clarke MF and Weissman IL: Stem cells, cancer and cancer stem cells. Nature 414: 105-111, 2001.

2. Passegué E, Jamieson CH, Ailles LE and Weissman IL: Normal and leukemic hematopoiesis: Are leukemias a stem cell disorder or a reacquisition of stem cell characteristics? Proc Natl Acad Sci USA 100 (Suppl 1): 11842-11849, 2003.

3. Warner JK, Wang JCY, Hope KJ, Jin L and Dick JE: Concepts of human leukemic development. Oncogene 23: 7164-7177, 2004.

4. Huntly BJ and Gilliland DG: Leukaemia stem cells and the evolution of cancer-stem-cell research. Nat Rev Cancer 5: 311-321, 2005.

5. Weissman I: Stem cell research: Paths to cancer therapies and regenerative medicine. JAMA 294: 1359-1366, 2005.

6. Costello R, Mallet F, Chambost H, Sainty D, Arnoulet C, Gastaut JA and Olive D: The immunophenotype of minimally differentiated acute myeloid leukemia (AML-M0): Reduced immunogenicity and high frequency of $\mathrm{CD} 34^{+} / \mathrm{CD} 38^{-}$leukemic progenitors. Leukemia 13: 1513-1518, 1999.

7. van Rhenen A, Feller N, Kelder A, Westra AH, Rombouts E, Zweegman S, van der Pol MA, Waisfisz Q, Ossenkoppele GJ and Schuurhuis GJ: High stem cell frequency in acute myeloid leukemia at diagnosis predicts high minimal residual disease and poor survival. Clin Cancer Res 11: 6520-6527, 2005

8. Bonnet D and Dick JE: Human acute myeloid leukemia is organized as a hierarchy that originates from a primitive hematopoietic cell. Nat Med 3: 730-737, 1997.

9. Malaise M, Steinbach D and Corbacioglu S: Clinical implications of c-Kit mutations in acute myelogenous leukemia. Curr Hematol Malig Rep 4: 77-82, 2009. 
10. Wakita S, Yamaguchi H, Miyake K, Mitamura Y, Kosaka F, Dan K and Inokuchi K: Importance of c-kit mutation detection method sensitivity in prognostic analyses of $\mathrm{t}(8 ; 21)(\mathrm{q} 22 ; \mathrm{q} 22)$ acute myeloid leukemia. Leukemia 25: 1423-1432, 2011.

11. Park SH, Chi HS, Min SK, Park BG, Jang S and Park CJ: Prognostic impact of c-KIT mutations in core binding factor acute myeloid leukemia. Leuk Res 35: 1376-1383, 2011.

12. Chao MP, Alizadeh AA, Tang C, Jan M, Weissman-Tsukamoto R, Zhao F, Park CY, Weissman IL and Majeti R: Therapeutic antibody targeting of CD47 eliminates human acute lymphoblastic leukemia. Cancer Res 71: 1374-1384, 2011.

13. Gerber JM, Smith BD, Ngwang B, Zhang H, Vala MS Morsberger L, Galkin S, Collector MI, Perkins B, Levis MJ, et al: A clinically relevant population of leukemic CD34(+)CD38(-) cells in acute myeloid leukemia. Blood 119: 3571-3577, 2012.

14. Meyer D, Seth S, Albrecht J, Maier MK, du Pasquier L, Ravens I, Dreyer L, Burger R, Gramatzki M, Schwinzer R, et al: CD96 interaction with CD155 via tts first Ig-like domain is modulated by alternative splicing or mutations in distal Ig-like domains. J Biol Chem 284: 2235-2244, 2009.

15. Fuchs A, Cella M, Giurisato E, Shaw AS and Colonna M: Cutting edge: CD96 (tactile) promotes NK cell-target cell adhesion by interacting with the poliovirus receptor (CD155). J Immunol 172: 3994-3998, 2004.

16. Hosen N, Park CY, Tatsumi N, Oji Y, Sugiyama H, Gramatzki M, Krensky AM and Weissman IL: CD96 is a leukemic stem cell-specific marker in human acute myeloid leukemia. Proc Natl Acad Sci USA 104: 11008-11013, 2007.

17. Gramatzki M, Ludwig WD, Burger R, Moos P, Rohwer P, Grünert C, Sendler A, Kalden JR, Andreesen R, Henschke F, et al: Antibodies TC-12 ('unique') and TH-111 (CD96) characterize T-cell acute lymphoblastic leukemia and a subgroup of acute myeloid leukemia. Exp Hematol 26: 1209-1214, 1998.
18. Löwenberg B, Downing JR and Burnett A: Acute myeloid leukemia. N Engl J Med 341: 1051-1062, 1999.

19. Wang PL, O'Farrell S, Clayberger C and Krensky AM Identification and molecular cloning of tactile. A novel human $\mathrm{T}$ cell activation antigen that is a member of the Ig gene superfamily. J Immunol 148: 2600-2608, 1992.

20. Ebinger M, Witte KE, Ahlers J, Schäfer I, André M, Kerst G, Scheel-Walter HG, Lang P and Handgretinger R: High frequency of immature cells at diagnosis predicts high minimal residual disease level in childhood acute lymphoblastic leukemia. Leuk Res 34: 1139-1142, 2010.

21. Witte KE, Ahlers J, Schäfer I, André M, Kerst G, Scheel-Walter HG, Schwarze CP, Pfeiffer M, Lang P, Handgretinger R, et al: High proportion of leukemic stem cells at diagnosis is correlated with unfavorable prognosis in childhood acute myeloid leukemia. Pediatr Hematol Oncol 28: 91-99, 2011.

22. Castor A, Nilsson L, Astrand-Grundström I, Buitenhuis M, Ramirez C, Anderson K, Strömbeck B, Garwicz S, Békássy AN, Schmiegelow K, et al: Distinct patterns of hematopoietic stem cell involvement in acute lymphoblastic leukemia. Nat Med 11: 630-637, 2005.

23. Hong D, Gupta R, Ancliff P, Atzberger A, Brown J, Soneji S, Green J, Colman S, Piacibello W, Buckle V, et al: Initiating and cancer-propagating cells in TEL-AML1-associated childhood leukemia. Science 319: 336-339, 2008.

24. Adams GP and Weiner LM: Monoclonal antibody therapy of cancer. Nat Biotechnol 23: 1147-1157, 2005. 